\title{
Legal Immigration Will Resolve America's Real Border Problems
}

By David J. Bier

\section{EXECUTIVE SUMMARY}

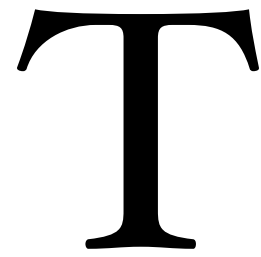

he U.S. government has allowed its asylum and border processing system to become overwhelmed. Central Americans are crossing illegally and often relying on asylum and other processing procedures at the border because they are virtually the only ways for them to enter the United States. After numerous failed attempts to deter the flow or restrict asylum, the most realistic and humane way to control the border is for Congress and the administration to channel future immigrants into an orderly legal structure for coming to the country.

Five reforms would make the asylum system manageable again and restore control over the border:

I. Humanitarian parole: Waive entry restrictions for Central Americans in the backlogged green card lines and with family legally in the United States.

2. Private refugee sponsorship: Allow U.S. residents and organizations to sponsor refugees from abroad as the State Department had planned in 2016.

3. Guest worker expansion: Expand the $\mathrm{H}-2 \mathrm{~A}$ and $\mathrm{H}-2 \mathrm{~B}$ seasonal worker programs to year-round jobs for Central Americans and waive the $\mathrm{H}-2 \mathrm{~B}$ cap.

4. Legalization: Legalize illegal immigrants who have no serious criminal convictions and let them reunite with their spouses and children, eliminating the network for future illegal immigration.

5. Processing at ports: Remove the cap on asylum seekers at ports of entry, process Ioo percent of their claims there, and release them with an employment authorization document contingent on them appearing in court.

These reforms will not stop all asylum seekers, but they will redirect enough of the flow into other legal channels to make the asylum process manageable again for U.S. authorities. 
The vast

majority of immigrants coming to the U.S.-Mexico border clearly want the opportunity to enter a legal process.

\section{INTRODUCTION}

"We were looking for the immigration office," Elmer Danilo Díaz Hernández told a Border Patrol agent after he crossed the border illegally with his 13 -year-old son in $2018 .{ }^{\mathrm{I}}$ Like Hernández, 70 percent of immigrants who cross the U.S.-Mexico border this year will not seek to evade detection, according to the Department of Homeland Security. ${ }^{2}$ Instead, they will intentionally seek out Border Patrol, treating the enforcement agency as an "immigration office"-a part of the legal U.S. immigration system. In Texas, immigrants line up at the border fence's gate, whichbecause the fence is on the U.S. side of the Rio Grande-the agents open to process those waiting to be "apprehended."3

The vast majority of immigrants coming to the U.S.-Mexico border clearly want the opportunity to enter a legal process, and many of them are accessing the only legal process available to them: asylum and related procedures. While U.S. law permits the fast removal of any noncitizen stopped at the border without documents, this rule has two exceptions. The exceptions apply to asylum seekers and their minor children who demonstrate a credible Figure 1

Border asylum requests and apprehensions of families and unaccompanied children, FY 2009-FY 2019

$400 \mathrm{~K}$

$200 K$

0 2009
2011

Sources: U.S. Citizenship and Immigration Services, Credible Fear Workload Report Summary, 2008-2019; Customs and Border Protection, Southwest Border Migration; Customs and Border Protection, Sector Profiles, 2011-2018.

Notes: *2019 figures are annualized; 2009-2011 families estimated based on accompanied children. 
2019, families were often released even without requesting asylum because the government had nowhere to detain them pending an asylum interview or their removal.

Of the immigrants who claimed a credible fear of persecution to start the asylum process in 20I4, just 5 percent had received asylum or other relief from deportation by the end of fiscal year (FY) 20I7, while the government deported 33 percent of them and ordered deported another I4 percent who hadn't yet left. ${ }^{7}$ The rest-nearly half of all the asylum seekers-remained in removal proceedings three years after their initial contact with authorities. If current trends continue, about half of all asylum seekers will likely end up with a removal order that is never executed (i.e., will become illegal immigrants). Unaccompanied children have had similar outcomes.

This new flow of immigrants to the border is a marginal improvement on traditional illegal immigration as it is less dangerous for the migrants and is easier for Border Patrol to monitor. ${ }^{8}$ Despite these marginal benefits, the situation poses many of the same problems as traditional illegal immigration in which migrants attempt to evade detection. It consumes significant law enforcement resources, Figure 2

Permanent visas, temporary work visas, and U.S. border apprehensions for Northern Triangle immigrants, FY 2015-FY 2019

$600 \mathrm{~K}$

$400 K$

$200 K$

0

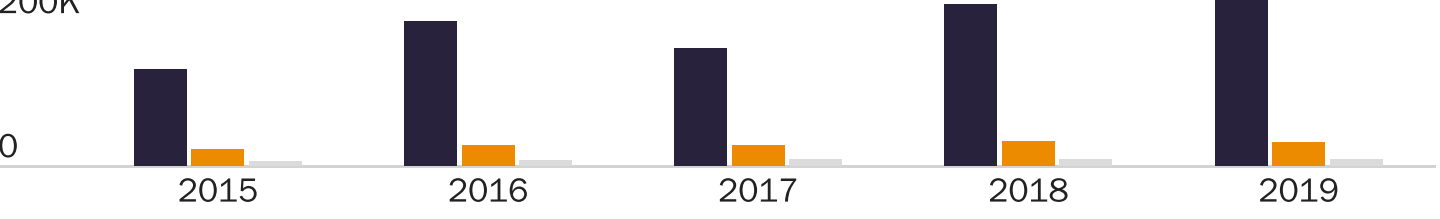

immigrants often pay thousands of dollars to criminal organizations to traffic themselves to the U.S.-Mexico border, and many are victimized. America can do better.

\section{THE SOLUTIONS: MORE LEGAL OPTIONS TO IMMIGRATE}

Central Americans choose to come to the United States because it is the safest, freest, and most prosperous country that they can reach. The fundamental cause of the border surge is that crossing the border is a far more effective method for Central Americans to enter the United States than using the rest of the U.S. immigration system. Figure 2 highlights the disconnect between the number of visas and the number of people arriving at the border from the Northern Triangle. In 2019, border apprehensions of Central Americans are on pace to outnumber permanent visas issued to Central Americans by more than 20 to one. For temporary work visas, the ratio is 78 :I.

Currently, the government releases most asylum seekers into the interior of the United States because it lacks detention space to hold all of them, making it a viable method to enter even if the immigration courts ultimately deny
${ }^{66}$ The

fundamental

cause of the border

surge is that

crossing the

border is a far

more effective

method

for Central

Americans

to enter the United

States than

using the rest of the U.S. immigration system. 
${ }^{66}$ The following five reforms would channel future immigrants into the legal immigration system, incentivize compliance, and restore integrity to the legal immigration system. 99 the asylum application. Asylum applicants also receive employment authorization if their application remains pending for 180 days. And the law requires the government to release unaccompanied children. Given the limited number of visas, Central Americans rationally calculate that they are more likely to gain access to the United States through the U.S.-Mexico border. The following five reforms take that reality into account and would channel future immigrants into the legal immigration system, incentivize compliance, and restore integrity to the legal immigration system.

\section{Solution 1: Parole for Green Card Applicants and U.S. Family}

The most pressing need is for the government to allow immigrants to reunite with their families in the United States, which is a powerful mechanism enabling immigration (even if it is not the underlying reason for it). ${ }^{9}$ As early as 20I4, over 90 percent of Central American child migrants had at least one family member in the United States. ${ }^{10}$ Also that year, the United Nations High Commissioner for Refugees found that 8I percent of Central American children left their home countries, in part, to reunite with family members in the United States or for economic or educational opportunity. ${ }^{\mathrm{II}}$ Adult Central Americans also generally have family members in the United States. ${ }^{\mathrm{I} 2}$ The problem is that these arrivals have no legal way to reunite with these family members.

Fortunately, the Department of Homeland Security (DHS) has the authority to "parole into the United States . . . for urgent humanitarian reasons ... any alien applying for admission to the United States" who is not otherwise qualified to enter. ${ }^{13}$ In the immigration context, "parole" is a waiver of immigration restrictions, allowing an immigrant to enter even if they do not fit into a specific category in the law. Paroled migrants receive only legal status and employment authorization, are ineligible for means-tested federal welfare programs, and cannot receive legal permanent residence (or, later, U.S. citizenship) unless they separately qualify through other existing pathways. ${ }^{\mathrm{I}}$ The administration should grant parole to immigrants still in the Northern Triangle if:

a. they have a green card petition approved on their behalf but cannot receive a visa due to the quotas; or

b. they have a spouse, parent, child, sibling, grandparent, or-in the case of children-an aunt or uncle with legal status in the United States.

The argument for humanitarian parole is very strong for the first group. Green card applicants have the right to come to the United States eventually, but green card limits-which Congress has not updated since $1990-$ impose such exceptionally long wait times that most eligible Central Americans cannot immigrate through these pathways for many years.

Immediate family of American citizens or green card holders currently have long wait times (Table I). New applicants for green cards from the Northern Triangle will have to wait up to 65 years in some cases, incentivizing many of them to come illegally rather than to apply for a visa that would not be issued until after they had died from old age (Table $\mathrm{I}$ ). ${ }^{15}$ Approximately I44,000 immigrants from the Northern Triangle would benefit from humanitarian parole. ${ }^{16}$ If these immigrants will be reuniting with the families in the United States either way, the government should assure that when they do, it is before they die of old age.

With such long waits, many applicants will never receive their green cards, and many others will likely never bother to apply at all. DHS should grant parole to these immigrants, allowing them to relocate immediately to the United States, and it should keep the program open to future green card applicants. This type of ongoing parole program for green card applicants would incentivize more immigrants to apply through these legal channels once they see that they are a viable and quick method to immigrate legally. This would have a dual benefit: it would decrease the cost of monitoring the border and save migrants from dangerous journeys, since many immigrants would skip 
Table 1

Estimated immigrant visa waiting list, visas issued, and years to wait for new Northern Triangle immigrants, 2018

\section{Immigrant visa waiting list in 2018}

El Salvador Hondura

\begin{tabular}{|l|r|r|r|r|}
\hline & El Salvador & Honduras & Guatemala & Total \\
\hline F1: Unmarried adult child of citizen & 9,140 & 4,448 & 4,000 & 17,588 \\
\hline F2A: Spouse-child of resident & 6,898 & 3,434 & 4,015 & 14,347 \\
\hline F2B: Unmarried adult child of resident & 9,187 & 3,500 & 3,992 & 16,679 \\
\hline F3: Married adult child of citizen & 10,971 & 8,000 & 8,000 & 26,971 \\
\hline F4: Siblings of adult citizens & 28,460 & 20,000 & 20,000 & 68,460 \\
\hline Total & 64,656 & 39,382 & 40,007 & 144,045 \\
\hline
\end{tabular}

Immigrant visas issued in 2018

\begin{tabular}{|l|r|r|r|r|}
\hline & El Salvador & Honduras & Guatemala & Total \\
\hline F1: Unmarried adult child of citizen & 1,117 & 507 & 466 & 2,090 \\
\hline F2A: Spouse-child of resident & 3,368 & 1,017 & 1,603 & 5,988 \\
\hline F2B: Unmarried adult child of resident & 1,225 & 230 & 396 & 1,851 \\
\hline F3: Married adult child of citizen & 335 & 160 & 125 & 620 \\
\hline F4: Siblings of adult citizens & 902 & 308 & 369 & 1,579 \\
\hline Total & 6,947 & 2,222 & 2,959 & 12,128 \\
\hline \multicolumn{1}{|c|}{ Projected years to wait for new applicants } & Honduras & Guatemala & Average \\
\hline & El Salvador & 8 & 9 & 9 \\
\hline F1: Unmarried adult child of citizen & 2 & 3 & 8 \\
\hline F2A: Spouse-child of resident & 7 & 15 & 10 & 9 \\
\hline F2B: Unmarried adult child of resident & 33 & 50 & 64 & 44 \\
\hline F3: Married adult child of citizen & 32 & 65 & 54 & 43 \\
\hline F4: Siblings of adult citizens
\end{tabular}

Sources: U.S. Department of State, Annual Report of the Visa Office; U.S. Department of State, Annual Report of Immigrant Visa Applicants.

Note: Years to wait were projected by the author by dividing the number of applicants by the number of visas issued in 2018.

the hazardous trek through Mexico if they used humanitarian parole.

In addition to this program, DHS should initiate a broader parole program for family reunification for anyone with a close relative in the United States who holds any legal statuscitizenship, legal permanent resident status, temporary protected status, parole, etc. DHS should define close relatives as spouses, children, parents, siblings, and grandparents of the immigrants as well as aunts and uncles if the immigrant is a minor. There are currently no immigration categories for these relationships, or the pathways require the U.S. family member to be a U.S. citizen or legal permanent resident, excluding people with other legal statuses. As an example, one Central American woman who was seeking asylum and who reunited with her U.S. citizen teenage daughter in Denver after crossing the border was ineligible for sponsorship because her daughter was a minor. ${ }^{17}$

While it is unclear how many people would benefit from this provision, the approximately I.3 million Salvadorans, Guatemalans, and Hondurans who had legal status in the United States already in 2016 give some indication (Table 2). ${ }^{18}$ About three-quarters of
${ }^{66}$ DHS should initiate a broader parole program for family reunification for anyone with a close relative in the United States who holds any legal status. 99 
66 The problem is that the U.S. refugee program in Central America is virtually nonexistent, and refugees cannot apply directly to it. 9

Table 2

Immigrants from the Northern Triangle by status, 2016

\begin{tabular}{|l|r|r|r|r|}
\hline & Illegal & Legal noncitizen & \multicolumn{1}{c|}{ Citizen } & \multicolumn{1}{c|}{ Total } \\
\hline El Salvador & 725,000 & 207,000 & 488,000 & $1,420,000$ \\
\hline Guatemala & 575,000 & 119,000 & 286,000 & 980,000 \\
\hline Honduras & 425,000 & 42,000 & 163,000 & 630,000 \\
\hline Total & $1,725,000$ & 368,000 & 937,000 & $3,030,000$ \\
\hline
\end{tabular}

Sources: "Unauthorized Immigrant Population Trends for States, Birth Countries and Regions," Pew Research Center, November 27, 2018; "American Community Survey 1-Year Data 2016," U.S. Census Bureau.

them-937,000-were U.S. citizens, and another 368 ,ooo were legal noncitizens with various statuses.

DHS should prioritize reuniting Central Americans with legal U.S. family members. People who have U.S. family are far more likely to immigrate here than others, and humanitarian parole would incentivize them to use the legal system. It also would further reward people who have relied on the legal immigration options and so create another positive incentive to obey the law.

\section{Solution 2: Private Refugee Sponsorship by U.S. Individuals and Entities}

The second group that should receive immediate attention are immigrants who were forced to flee their home countries due to wellfounded fears of persecution. U.S. law labels these immigrants "refugees" if they receive processing overseas or "asylees" if they apply in the United States. ${ }^{19}$ Although most immigrants arriving at the border from Central America will not receive asylum, about one in six people at the border who assert a credible fear of persecution do receive asylum by proving their cases in immigration court. ${ }^{20}$

This fact shows that many Central Americans could qualify for the refugee program, which would enable them to apply outside the United States rather than at the border. The problem is that the U.S. refugee program in Central America is virtually nonexistent, and refugees cannot apply directly to it. By the end of FY 2019, the program will have admitted fewer than 3, Ooo refugees from the Northern Triangle since FY 2015, while people from the Northern Triangle will have made nearly 275,000 asylum claims at the border (Figure 3). ${ }^{2 \mathrm{I}}$ Since 2015, there have been about 96 asylum claims by Central Americans at the border for each refugee admitted from Central America.

The most difficult part of starting a refugee program is identifying refugees for resettlement. Generally, the U.S. Refugee Admissions Program relies on referrals from the United Nations High Commissioner for Refugees (UNHCR). This process works most effectively when the refugee population is broad and easily identifiable based on direct government persecution. Generally, UNHCR refers refugees who it knows need resettlement from camps where they have lived for a protracted period and have little hope of returning home. In Central America, however, refugee claims are largely based on private violence that the government refuses to investigate, and there are no refugee camps. ${ }^{22}$ In those cases, having private actors like family members, nonprofit organizations, and churches identify refugees is superior to relying on UNHCR.

These private actors would submit requests to the U.S. Department of State to resettle refugees that they have identified. If the private actors pay the costs of processing the application and bringing the refugees to the United States, the program would reduce the number of candidates without legitimate refugee claims and provide a funding mechanism to process them quickly. If processing is exceptionally slow, immigrants may decide to head to the U.S.Mexico border anyway, undermining the main purpose of the program. Although refugees traditionally have not paid normal administrative processing fees, rapid processing would be so 
Figure 3

Border asylum claims and refugee entries by Northern Triangle nationals, FY 2015-FY 2019

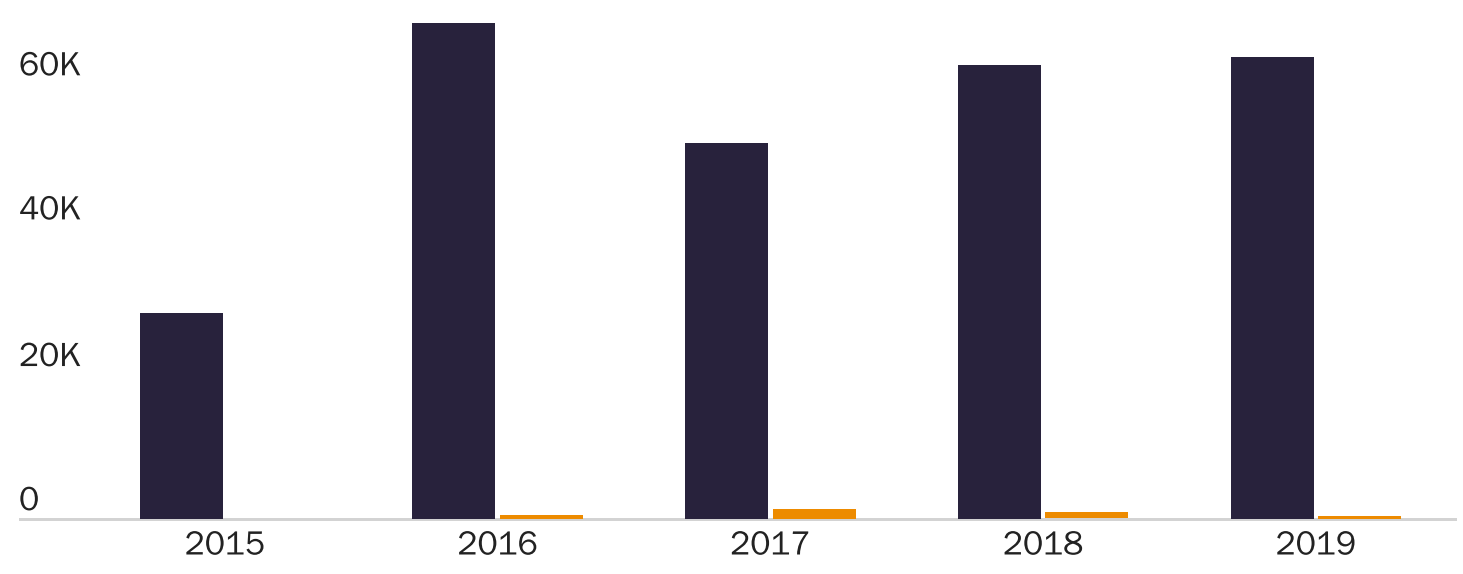

important for expanded refugee resettlement from Central America that the government should adopt a fee structure anyway.

Private refugee sponsorship is not unprecedented. Canada has had a private sponsorship system for refugees since the late I970s, and more than 275,000 refugees have used it. ${ }^{23}$ The United States also briefly had a private refugee sponsorship program for Cubans and Soviet Jews in the late 1980 s and early 1990 s. $^{24}$ The Obama administration adopted a family refugee sponsorship program when it created the Central American Minor (CAM) program in 2OI4. CAM allowed U.S.-based parents with legal status to request resettlement on behalf of their children. Unfortunately, its narrow criteria only allowed a few thousand children to apply. In late 2016, the State Department announced plans to create a broader pilot program for private refugee sponsorship in 2017, which would have allowed private organizations and individuals to sponsor refugees without family ties. ${ }^{25}$ The Trump administration failed to implement the pilot program, and it cancelled the CAM program. ${ }^{26}$

A private sponsorship program could begin almost immediately without needing to involve UNHCR. Sponsors would submit an affidavit of support that shows that they have the resources to fund the refugees' initial resettlement and includes a pledge to support them if they are unable to support themselves in their first two years in the country. Moreover, the Department of State should make it possible for refugees to apply directly to the program, and U.S. private actors could decide which refugees they want to sponsor. Allowing refugees to enter a legal humanitarian immigration process in their home countries (if possible) or in a country to which they have fled would give them a reason to await adjudication of their application and ultimately sponsorship rather than immediately heading to the United States.

\section{Solution 3: Expand Guest Worker Programs in Central America}

Family reunification and persecution motivate a significant portion of Central American migration, but economic opportunity and employment remain the most important factors in drawing Central Americans to the border. In one typical example, Honduran Héctor Romero told the New York Times in January 2019 that he 
${ }^{66}$ To address the economic drivers of migration, Congress needs to expand guest worker programs or create such programs for migrants from the Northern Triangle. 99 would head north because: "I have had only two days' work a week for the past three months and that barely covers expenses." 27 In 20I4, 87 percent of Central Americans apprehended in Mexico told Mexican officials that lack of employment, low wages, and poor working conditions were their primary motivations for leaving their home countries. ${ }^{28}$ A 2017 survey of Central Americans found that employment and wages dominated the reasons for relocating. ${ }^{29}$ Nearly all Guatemalans, 94 percent of Hondurans, and 66 percent of Salvadorans exclusively cited economic motivations. ${ }^{30}$

To address the economic drivers of migration, Congress needs to expand guest worker programs or create such programs for migrants from the Northern Triangle to channel them into legal employment. Worker programs have already effectively controlled illegal immigration from Mexico-the largest historical source of people crossing illegally into the United States. ${ }^{3 \mathrm{I}}$ Despite the increase in apprehensions of Central Americans by Border Patrol, apprehensions overall have declined since the early 200os due to more Mexican immigrants using the guest worker visa programs.

Figure 4

\section{Lesser-skilled guest worker entries and apprehensions per Border Patrol agent, FY 1949-FY 2018}
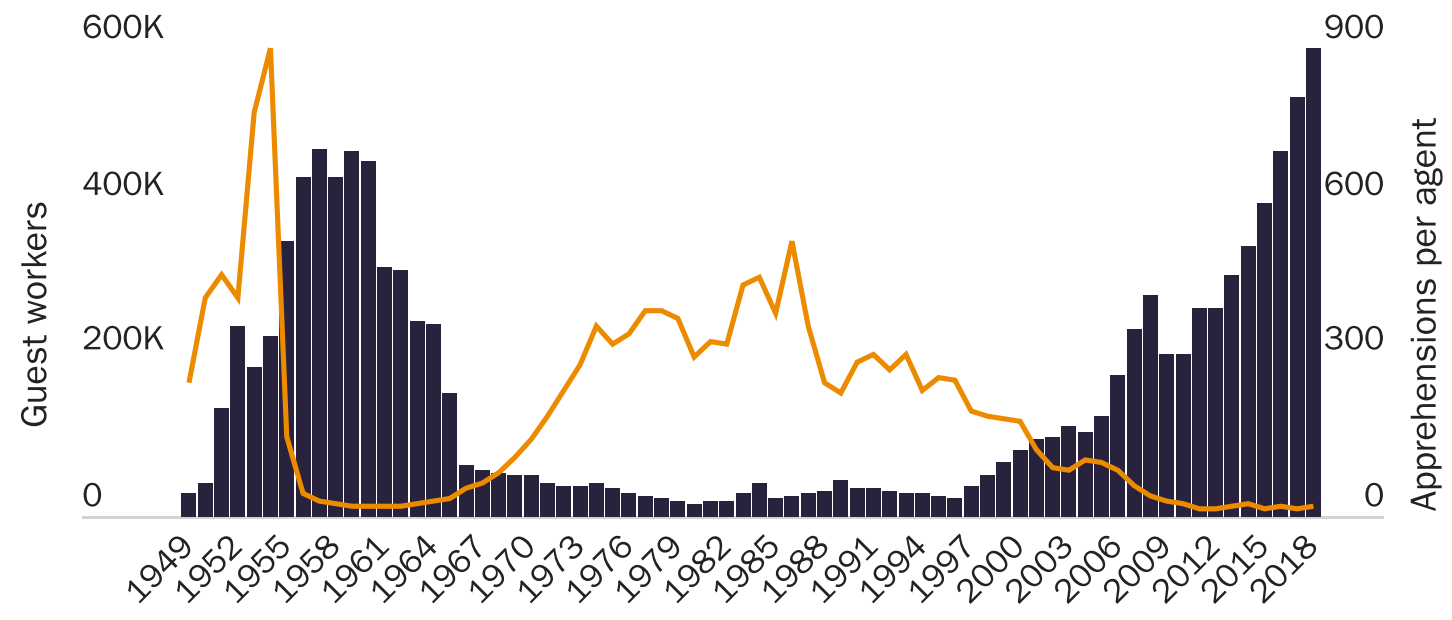

Figure 4 compares entries under lowprehensions per Border Patrol agent from FY 1949 to FY 2018. Researchers use apprehensions as a proxy for illegal crossings, but because more agents can result in more apprehensions without more people crossing, it is important to control for the amount of border enforcement by looking at the number of apprehensions per Border Patrol agent. As Figures 4 shows, when illegal immigration first spiked in the early I950s, Congress responded both with enforcement and guest worker liberalization under the bracero program for Mexican seasonal agricultural workers. Border Patrol even walked many illegal immigrants to the border, handed them a work visa, and readmitted them legally. ${ }^{32}$

The bracero guest worker expansion resulted in a massive decline in illegal immigration. When Congress allowed the program to sunset in 1965, illegal immigration returned for four decades of large-scale uninterrupted crossings. At the time, Border Patrol agents fiercely opposed the elimination of the bracero program, correctly predicting that it skilled guest worker visa programs and ap-

Sources: "General Collection," U.S. Citizenship and Immigration Services, 1949-1995; U.S. Department of Homeland Security, Yearbook of Immigration Statistics, 1996-2017; Immigration and Naturalization Service, History: Border Patrol, 1985; TRAC Immigration, Border Patrol Agents, 2006; Border Patrol, Staffing Statistics, December 12, 2017.

Note: 2018 figures based on the percentage increase in H-2 visa issuances from U.S. Department of State, Annual Report of the Visa Office, 2018. 
would result in more illegal immigration than the agency could realistically expect to control. "We can't do the impossible," one Border Patrol official told Congress when asked if the agency could stop illegal immigration without the bracero program. ${ }^{33}$

Since the late I990s, however, the number of worker admissions has risen almost continuously. The $\mathrm{H}-2 \mathrm{~A}$ and $\mathrm{H}-2 \mathrm{~B}$ visa system-for seasonal agricultural $(\mathrm{H}-2 \mathrm{~A})$ and nonagricultural $(\mathrm{H}-2 \mathrm{~B})$ positions, respectively-came into existence in 1987 , but it took time for employers to learn how to navigate the regulations. As Figure 5 shows, nearly 99 percent of the increase in worker admissions have come from Mexico, while very few have come from the Northern Triangle countries in Central America.

Guest worker programs have effectively controlled illegal immigration from Mexico, and they could do the same for Central America. Work visas need not be issued to everyone who would otherwise come illegally, but their widely known availability creates an expectation that a person could receive a visa in the future if they wait. "Most of my friends go with visas or they don't go at all," one Mexican worker said in 2019. Although he had not yet received a visa, his prior experience working in the United States under the H-2A program gave him a reason to wait. He told the Washington Post that he wants to be "working in the United States - but only with a visa."34 That explains why, from FY 1996 to FY 2019, every H-2 worker's admission from Mexico was associated with a decrease in two border apprehensions of Mexicans. ${ }^{35}$

Central Americans would cherish the same opportunity. In fact, because asylum seekers are eligible for employment authorization after their application has been pending for I80 days, the United States already has a de facto worker program for Central America, just one that requires the workers to travel to the border and ask for asylum. ${ }^{36}$ DHS issued more than 345 , 000 employment authorization documents to immigrants with pending asylum claims in FY 2018 (Figure 6). ${ }^{37}$ This means that in practice, the asylum program is already a much larger worker program than the $\mathrm{H}-2$ guest worker programs, which issued 280 , 000 visas total in FY $2018 .{ }^{38} \mathrm{FY} 2018$ was even a down year for asylum employment authorizations due to fewer asylum requests at the border in 2017 . In FY 2017, more than

Figure 5

H-2 Seasonal worker admissions, FY 1996-FY 2019

$800 \mathrm{~K}$

$600 \mathrm{~K}$

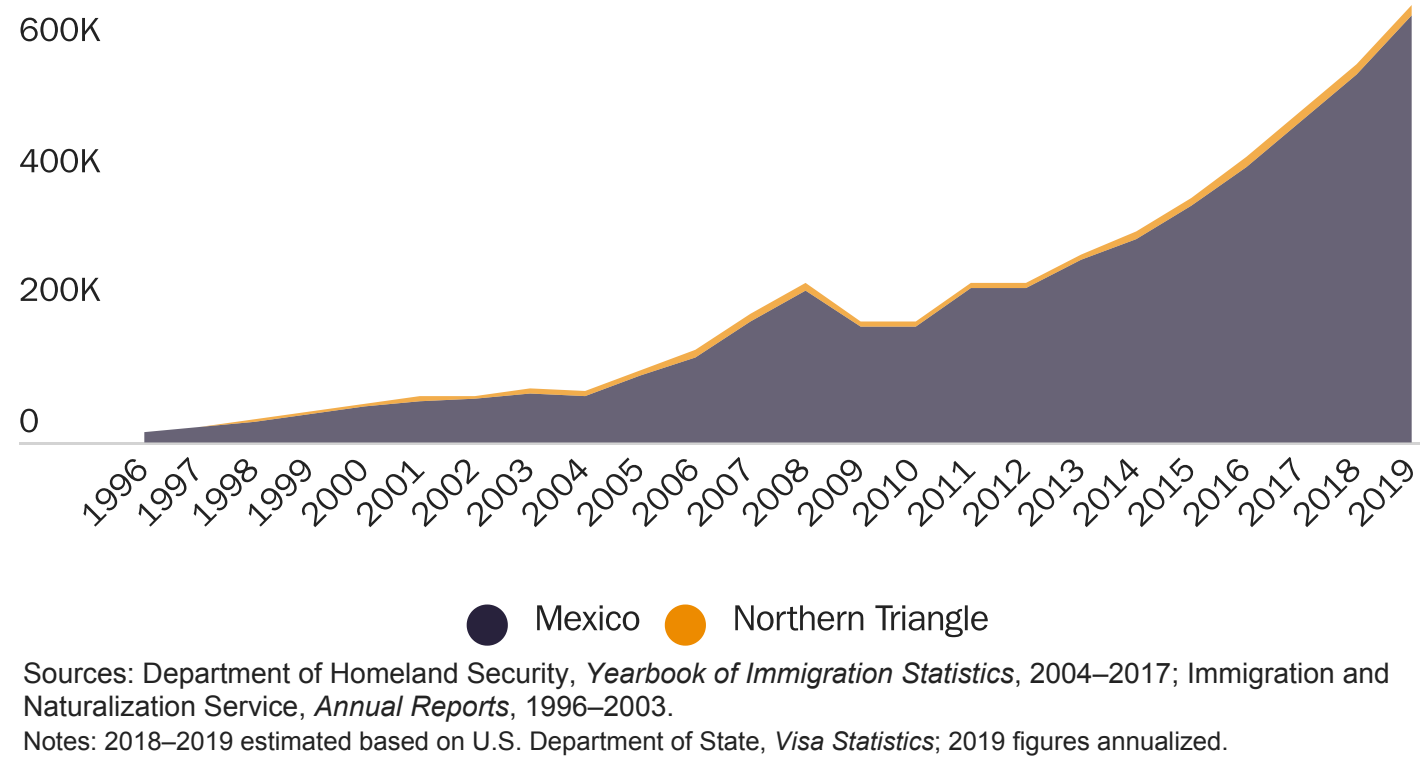


Figure 6

Congress should create incentives for U.S. recruiters of temporary workers to establish operations in the Northern Triangle.

\section{Employment authorization documents and new H-2 work visas issued, FY 2012-FY 2018}

$400 K$

$200 K$

0

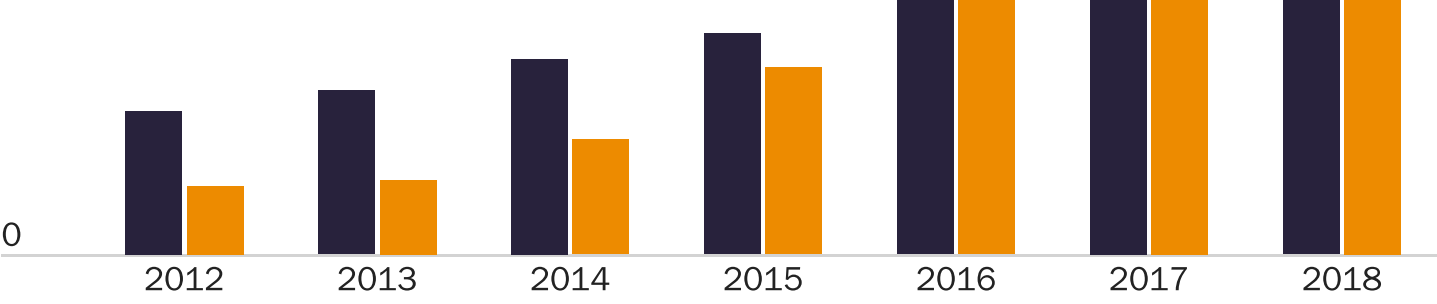

$\mathrm{H}-2$ work visas

Asylum employment authorization

Sources: U.S. Citizenship and Immigration Services, Number of Approved Employment Authorization Documents; U.S. Department of State, Annual Report of the Visa Office.

400,000 were issued, reflecting higher border flows the year before. It is likely that FY 2019 will exceed the 2017 record and that $\mathrm{FY} 2020$ will blow it away.

Nearly all $\mathrm{H}-2$ visas have gone to Mexicans for several reasons. First, migrant workers cannot apply directly for $\mathrm{H}-2$ visas. U.S. employers must recruit the workers and petition for visas on their behalf, and employers have no incentive to recruit in the Northern Triangle. ${ }^{39}$ Second, with about 130 million people, Mexico has a much bigger labor market in which to recruit. By comparison, the three Northern Triangle countries have just 33 million combined, and the largest-Guatemala-has only I7 million. As long as U.S. wages remain much higher than Mexican wages, employers can always find enough willing workers in Mexico alone. Third, U.S. recruiters of foreign workers already operate in Mexico, so the marginal costs of recruiting additional workers there is approaching zero. And Central Americans cannot simply go to Mexico to meet with U.S. recruiters there because U.S. law requires each worker to prove "a residence in a foreign country which he has no intention of abandoning." ${ }^{\circ} \mathrm{A}$ A Central American who has already abandoned his country once would not meet this requirement.

Given this situation, Congress has three options to make work visas more readily available in Central America: it could design a new worker program, throw out several of the rules of the existing system, or give an incentive for U.S. recruiters to set up in Central America. With the conservative nature of government, the last option seems like the most politically realistic in the short term.

Congress should create incentives for U.S. recruiters of temporary workers to establish operations in the Northern Triangle. Here is one way in which to create such incentives:

- For Guatemala, Congress should let U.S. employers hire $\mathrm{H}-2 \mathrm{~A}$ agricultural workers even in nonseasonal or temporary positions.

- For El Salvador, it should permit H-2B nonagricultural workers to enter and work above the visa cap of 66,000 but only in seasonal positions.

- For Honduras, it should also waive the $\mathrm{H}-2 \mathrm{~B}$ cap but only in nonseasonal positions. 
Which country receives which carveout is less important than that Congress give recruiters a reason to operate in each country. The recruiters would also bear the burden of advertising the availability of these new visas, countering narratives from smugglers that the only way to reach the United States is through Mexico. No single reform is more important to solving the asylum crisis than making guest worker programs more available to Central Americans.

\section{Solution 4: Legalization of Existing Illegal Immigrants and Asylum Seekers}

None of the above proposed reforms would address two of the biggest problems for the asylum system-the immense backlog of immigration court cases and the number of asylum seekers already in the process, most of whom will not end up receiving any form of legal status. Congress should grant a permanent legal status to the current illegal and asylum-seeking populations, which would clear immigration court backlogs, prevent asylum seekers from becoming illegal immigrants, and allow family of the legalized immigrants to reunite legally.

The court backlog has led to the breakdown of the entire asylum and removal process. As of March 2019, the immigration courts had a backlog of about 870,000 cases. $^{4 \mathrm{I}}$ In 20I9, the average case took $4 \mathrm{I} 8$ days for Guatemalans, 44I days for Hondurans, and 7 I4 days for Salvadorans. ${ }^{42}$ These durations had all doubled or tripled since 2009 , and in many courts, new cases in early 2019 were being scheduled for $2022 .{ }^{43}$ With waits of these lengths, any new applicants either need to be detained for periods that rival the punishments handed out to felons or released. Either way, it is not a manageable situation.

Congress must hit the reset button on immigration. That process starts with establishing legal channels for future immigrants, but it needs to conclude with a recognition that the existing population of illegal immigrants and asylum seekers cannot be efficiently dealt with under the current process and are not going to be deported. Legalization of the current illegal population would clear the backlogs and restore order to the immigration courts.

As important, Congress should realize that the millions of illegal immigrants and asylum seekers already in the United States provide a network to facilitate the travel and entrance of new illegal immigrants and asylum seekers. Karla Gonzalez, for instance, came from Honduras with just her youngest child but eventually sent for her two older children in $2018 .{ }^{44}$ Legalizing them and providing them a legal way to reunite with their families is crucial to diverting the flow into legal channels and regulating the border. In 2016 , there were already 1.7 million illegal immigrants from the Northern Triangle in the United States. ${ }^{45}$ Congress cannot create a legal immigration program to reunite immigrants with illegal immigrant families in the United States, but it can and should allow for the reunification of families of newly legalized immigrants.

Of course, legalization could draw more people to come to the border on the erroneous belief that they might benefit or benefit from a future legalization. This is why the government should pair legalization with an expansion of legal immigration along the lines proposed above. Ultimately, legalization is necessary to stop illegal immigration by making legal immigration possible again for the family members of legalized immigrants.

\section{Solution 5: Process All Asylum Seekers at Ports of Entry}

The four reforms proposed above will not eliminate asylum, and some people will still come to the border seeking a haven. The final component of reform should focus on processing asylum seekers in a way that minimizes the security and humanitarian challenges posed by the current system. No single goal should be more important to Customs and Border Protection (CBP) in this respect than processing IOO percent of asylum seekers at ports of entry. Unfortunately, the agency has created a perverse set of incentives that discourage legal entry and encourage illegal entry:

\section{${ }^{66}$ No single reform \\ is more important to solving the asylum crisis than making guest worker programs more available to Central Americans.}


- First, at U.S. prompting, Mexico is intercepting immigrants before they can reach U.S. ports. Mexican agents then direct them to get on a legal immigration list and wait until their name is called. ${ }^{46}$ By contrast, immigrants who attempt to cross illegally largely are free to do so.

- Second, in April 2or8, CBP instituted a monthly cap of processing about IO,০০০ undocumented migrants-including asylum seekers-at ports of entry. This means that asylum seekers must wait for months, homeless, in dangerous Mexican cities. ${ }^{47}$ By contrast, Border Patrol immediately processes asylum seekers who cross illegally. ${ }^{48}$

- Third, CBP detains Ioo percent of asylum seekers at ports of entry for transfer to interior detention facilities. ${ }^{49} \mathrm{By}$ contrast, Border Patrol has released tens of thousands of immigrant families apprehended between ports without Border Patrol transferring them for further processing in the interior. ${ }^{\circ}$

- Fourth, CBP guarantees that Ioo percent of asylum seekers at ports of entry receive credible fear interviews, whichif an asylum officer finds no credible fear-result in the immediate removal of about one in four asylum seekers. ${ }^{5 \mathrm{I}}$ By contrast, Border Patrol is releasing families into the United States without setting up these interviews. ${ }^{52}$

These practices create perverse incentives for migrants to cross between ports of entry and not wait for legal processing at the ports. The government should reverse these incentives in every case. It should remove the cap on asylum seekers at ports of entry and work with the Mexican government to direct asylum seekers to ports of entry. While CBP complains of a lack of resources to process undocumented immigrants at ports, the agency had the capacity to process twice as many as its current monthly cap of IO,OOO at ports in October 20I6.53 CBP's complaints about resources refer to a lack of resources to process undocumented immigrants in the exact manner that it wants-with roo percent detention, IOo percent transfer to ICE detention, and IOO percent asylum interviews-as was the case before 2014 .

But CBP cannot process asylum seekers between ports of entry in that manner either. That is why Border Patrol is releasing families without interviews or detention. If the agency instead processed asylum seekers at ports with immediate release, it would incentivize people to follow the law and not cross illegally in dangerous and remote parts of the border. To incentivize asylum seekers to show up in court, DHS should issue them employment authorization that is contingent on their appearance in court. ${ }^{54}$ Currently, DHS grants employment authorization after I8o days. The department should also adopt other proven methods of obtaining compliance with court dates and removal orders, including community and electronic monitoring, legal orientation, and access to legal counsel. ${ }^{55}$

CBP at ports might need some assistance from Border Patrol agents to process everyone quickly, but the agency has been moving resources in the opposite direction: transferring 750 CBP port inspectors to Border Patrol to process illegal crossers. ${ }^{56}$ Indeed, despite claiming to hit its self-imposed capacity in early 2018 , the agency has not sped up processing at ports at all, while taking drastic steps to do so between ports. The fact is that CBP likely already can process (i.e., collect fingerprints, conduct background checks, and issue charging documents) all asylum seekers with the resources that it currently has at ports.

Until January 2017, CBP demonstrated that it could process asylum seekers in minutes for tens of thousands of Cubans applying under "wet foot, dry foot"-a policy that granted immediate release to Cubans seeking a haven on U.S. soil. As one Cuban explained in 2016, "They take your papers, ask you a series of questions, take your fingerprints, fill out some paperwork and then they say, 'Welcome to the United States." 57 Although the process for other asylum seekers would 
necessarily need to be somewhat differentincluding issuing them a charging document (i.e., a notice to appear in court) - the objection that quick processing for undocumented immigrants at ports is impossible given current resources is inaccurate.

Removing the cap on asylum seekers at ports would not stop the flow of asylum seekers-that would require other reforms (see above)-but it would ameliorate some negative consequences. Port processing would lessen the number of remote crossings and long detentions implicated in the deaths of several children in $2018 .^{5}$ In 2019, a father and his daughter drowned crossing the Rio Grande after CBP turned them away at a port of entry. ${ }^{59}$ Additionally, U.S. law considers crossing the border illegally a misdemeanor, so processing asylum seekers at ports would remove the criminal consequences and allow federal prosecutors to focus on other crimes. Processing all asylum seekers at ports would dramatically improve both the security and humanitarian issues associated with the asylum crisis.

\section{CONCLUSION}

Legal immigration is a proven and effective mechanism to manage migration. The first three legal immigration reforms outlined in this paper deal with each component of the current migration flows: (I) a parole program for families seeking to reunite, (2) a private sponsorship program for refugees fleeing violence, and (3) a work visa program for workers seeking economic opportunity. The last two proposals address the immigrants already at the borders or inside the United States seeking asylum: (4) legalizing the existing population of illegal immigrants and asylum seekers and (5) channeling future asylum seekers to ports of entry.

The reforms outlined in this paper would immediately relieve Border Patrol from having to spend so much of its time dealing with peaceful people seeking a better life in the United States. Awareness of the availability of legal options would create a virtuous cycle of people seeking them out and encouraging others to do so. The legal pathways would divert billions of dollars in smuggling fees away from cartels and criminal organizations and reduce the victimization of immigrants, including many children who pursue an unregulated and dangerous route to the U.S. border. The United States and immigrants seeking a haven here cannot afford another litany of failed efforts to address this humanitarian crisis.
66

Processing

all asylum

seekers at

ports would

dramatically

improve

both the

security and

humanitarian

issues

associated

with the

asylum

crisis. 


\section{NOTES}

I. Laura Meckler, Alicia A. Caldwell, and Dudley Althaus, “This Is Your Daughter? When Was She Born?' U.S. Border Agents Test Migrants' Claims of Family Ties," Wall Street Fournal, March 2, 2018.

2. Kevin McAleenan, acting secretary of the Department of Homeland Security, "Senate Judiciary Committee Hearing on Border Security," C-SPAN, June II, 20I9, I:52:57.

3. Nick Miroff and Karly Domb Sadof, "This Photo Shows Why a Border Wall Won't Stop the Immigration Surge," Washington Post, March 2I, 20I9.

\section{8 U.S.C. \$ I225; 8 U.S.C. \$II58; 8 U.S.C. \$ I232.}

5. Office of Inspector General, "Management Alert - DHS Needs to Address Dangerous Overcrowding among Single Adults at El Paso Del Norte Processing Center (Redacted)," Department of Homeland Security, OIG-I9-46, May 30, 2019.

6. Asylum Abuse: Is It Overwbelming Our Borders?, Hearing be-

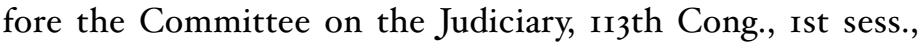
December I2, 20I3, p. I43; U.S. Citizenship and Immigration Services, Credible Fear Workload Summary, FY 20I4-FY 20I9; Customs and Border Protection, U.S. Border Patrol Southwest Border Apprebensions by Sector Fiscal Year 2019; Border Patrol, Sector Profiles, FY 20I2-FY 20I8, https://www.cbp.gov/ newsroom/media-resources/stats?title=sector+profile; Lesley Sapp, Apprehensions by the U.S. Border Patrol: 2005-20I0, Department of Homeland Security; Chad Haddal, Unaccompanied Alien Children: Policies and Issues, Congressional Research Service, January I5, 2009; U.S. Border Patrol, Unaccompanied Children (Age o-I7) Apprehensions: Fiscal Year 2008 through Fiscal Year 20I2, https://object.cato.org/sites/cato.org/files/wp-content/ uploads/uacs2oo8-20I2.pdf.

7. Office of Immigration Statistics, 2014 Soutbwest Border Encounters: Three-Year Cobort Outcomes Analysis, Department of Homeland Security, August 2018.

8. David Bier, "Fences Made Crossings Deadlier-Asylum Made Them Much Less So," Cato at Liberty, January 24, 2019.

9. Katharine M. Donato and Blake Sisk, "Children's Migration to the United States from Mexico and Central America: Evidence from the Mexican and Latin American Migration Projects," fournal on Migration and Human Security 3, no. I (2015): 58-79.
IO. Elizabeth G. Kennedy, “No Place for Children': Central America's Youth Exodus," Insight Crime, June 23, 20I4; 49 percent of Salvadoran unaccompanied children, 47 percent of Hondurans, and 27 percent of Guatemalans had at least one parent in the United States, according to United Nations High Commissioner for Refugees, Children on the Run: Unaccompanied Children Leaving Central America and Mexico and the Need for International Protection, 2014, p. 63.

II. United Nations High Commissioner for Refugees, Children on the Run, p. IO.

I2. Nick Miroff and Tim Meko, "A Snapshot of Where Migrants Go after Release into the United States," Washington Post, April I2, 2019 .

I3. 8 U.S.C. $\$ \operatorname{II} 82(d)(5)(A)$.

I4. National Immigration Law Center, Overview of Immigrant Eligibility for Federal Programs, October $201 \mathrm{I}$.

I5. U.S. Department of State, Annual Report of the Visa Office 2018, Table VI.

I6. U.S. Department of State, Annual Report of Immigrant Visa Applicants in the Family-sponsored and Employment-based Preferences Registered at the National Visa Center, November I, 2018.

I7. "Immigrant Mother Detained at ICE Facility Reunites with Daughter in Aurora," ABC7, July 3, 2018.

I8. "Unauthorized Immigrant Population Trends for States, Birth Countries and Regions," Pew Research Center, November 27, 20I8; D'Vera Cohn, Jeffrey Passel, and Ana GonzalezBarrera, Rise in U.S. Immigrants from El Salvador, Guatemala and Honduras Outpaces Growth from Elsewhere, Pew Research Center, December 7, 2017.

I9. 8 U.S.C. \$II57; 8 U.S.C. \$II58; 8 U.S.C. \$IIOI(a)(42).

20. Department of Justice, Executive Office for Immigration Review Adjudication Statistics: Asylum Decision and Filing Rates in Cases Originating with a Credible Fear Claim, April I2, 2019, https://www. justice.gov/eoir/page/file/ıo62976/download.

2I. "Admissions and Arrivals," U.S. Department of State, Refugee Processing Center, www.wrapsnet.org/admissions-andarrivals. 
22. Sofía Martínez, "Today's Migrant Flow Is Different," The Atlantic, June 26, 2018.

23. "Private Sponsorship of Refugees," Canadian Council for Refugees.

24. David Bier, "What Ronald Reagan Can Teach Us about Refugee Resettlement," Daily Caller, November I2, 2015.

25. "The Private Sector's Role in Refugee Resettlement," Private Sector Forum on Migration \& Refugees, Concordia, October 25, 20I6, New York, https://youtu.be/Qj89Ccvh8dk?t=II53.

26. Mica Rosenberg, "U.S. Ends Program for Central American Minors Fleeing Violence," Reuters, August I6, 2017.

27. Jeff Ernst, Elisabeth Malkin, and Paulina Villegas, "A New Migrant Caravan Forms, and Old Battle Lines Harden," New York Times, January I3, 2019.

28. Auditoría Superior de la Federación, Evalución Número 1787GB: Política Pública Migratoria, p. 5I.

29. El Colegio de La Frontera Norte, Encuesta sobre Migración en la Frontera Sur de México: Informe Anual de Resultados 2017, https://www.colef.mx/emif/resultados/informes/20I7/Emif\%2O Informe\%2OAnual\%2OSUR\%2O2OI7\%2O(26_abril_2OI9).pdf, p. 3 I.

30. According to the International Organization for Migration, 9I.I percent of Guatemalans in the United States in 2016 immigrated there for economic reasons; International Organization for Migration, Encuesta sobre Migración Internacional de Personas Guatemaltecas y Remesas 2016, February 2017, https://onu.org. gt/wp-content/uploads/2017/O2/Encuesta-sobre-MigraciOn-yRemesas-Guatemala-2or6.pdf, p. 42.

3r. Jens Manuel Krogstad and Jeffrey S. Passel, "U.S. Border Apprehensions of Mexicans Fall to Historic Lows," Pew Research Center, December 30, 2014 .

32. Kitty Calavita, Inside the State: The Bracero Program, Immigration, and the INS (New Orleans: Quid Pro Books, 2010), p. 43; Ernesto Galarza, Merchants of Labor: The Mexican Bracero Story (Charlotte, NC: McNally and Loftin Publishers: 1964), pp. 66-67.

33. Calavita, Inside the State, p. 68.
34. Kevin Sieff, "Why Is Mexican Migration Slowing While Guatemalan and Honduran Migration Is Surging?,"Washington Post, April 29, 2019.

35. Department of Homeland Security, Yearbook of Immigration Statistics, I996-2017, https://www.dhs.gov/immigrationstatistics/yearbook; U.S. Department of State, Annual Reports of the Visa Office, 20I8; U.S. Border Patrol, Total Illegal Alien Apprehensions by Fiscal Year, 2000-2018, https://www.cbp.gov/sites/ default/files/assets/documents/2or9-Mar/bp-total-apps-othermexico-fy2ooo-fy2or 8.pdf; Immigration and Naturalization Service, Yearbooks of Immigration Statistics, 2000, https://www. dhs.gov/immigration-statistics/yearbook/200o.

36. 8 CFR \$ 274a.I2(c)(8); 8 CFR \$ 208.7; 8 U.S.C. \$ II58(d)(2).

37. U.S. Citizenship and Immigration Services, Number of Approved Employment Authorization Documents, by Classification and Statutory Eligibility October I, 20II-September 30, 20I8, https://www.uscis.gov/sites/default/files/USCIS/ Resources/Reports\%20and\%20Studies/Immigration\%2O Forms\%2oData/BAHA/2._eads-by-statutory-eligibility_ Formatted_4-IO-I9.pdf.

38. "Nonimmigrant Visa Statistics," U.S. Department of State, https://travel.state.gov/content/travel/en/legal/visa-lawo/visastatistics/nonimmigrant-visa-statistics.html.

39. “2OI9 Revision of World Population Prospects," United Nations Population Division, https://population.un.org/wpp/.

40. 8 U.S.C. $\$ \operatorname{IIOI}(\mathrm{a})(\mathrm{I} 5)(\mathrm{h})(\mathrm{ii})$.

4I. "Immigration Court Backlog Tool," Trac Immigration, Syracuse University, 20I9, https:/trac.syr.edu/phptools/immigration/ court_backlog/.

42. "Immigration Court Processing Time by Outcome," Trac Immigration, Syracuse University, 20I9, https://trac.syr.edu/ phptools/immigration/court_backlog/court_proctime_outcome. php.

43. Noah Lanard, "The Shutdown Is Forcing Immigrants to Wait Years for a Court Hearing," Mother fones, January I5, 2019.

44. Chris Kenning, "Migrant Caravan Isn't an 'Invasion' to This Kentucky Mom, It's Her Kids," Louisville Courier Fournal, December I7, 2 OI8. 
45. "Unauthorized Immigrant Population Trends," Pew Research Center.

46. Al Otro Lado Inc. v. Nielsen, 327 F. Supp. $3 \mathrm{~d}$ I284 (S.D. Cal. Oct. I2, 2018); Human Rights First, Barred at the Border: Wait "Lists" Leave Asylum Seekers in Peril at Texas Ports of Entry, April 2019.

47. Elliot Spagat, Nomaan Merchant, and Patricio Espinoza, "For Thousands of Asylum Seekers, All They Can Do Is Wait," Associated Press, May 9, 2019; Daniella Silva, "Trapped in Tijuana: Migrants Face a Long, Dangerous Wait to Claim Asylum," NBC News, March I8, 2019.

48. Miroff and Sadof, "This Photo Shows Why."

49. Human Rights First, Refugee Blockade: The Trump Administration's Obstruction of Asylum Claims at the Border, December 2018.

50. Paul Ingram, "Tucson Border Patrol Bypassing ICE in Releasing Migrant Families," April 2, 2019, Tucson Sentinel.

51. U.S. Citizenship and Immigration Services, Credible Fear Workload Report Summary FY2019 Total Caseload.

52. Ingram, "Tucson Border Patrol Bypassing ICE.”
53. "Southwest Border Migration FY2017," Customs and Border Protection.

54. Shikha Dalmia, "The Cost-Free Way to End the Border Rush," The Week, April 3, 2019.

55. Alex Nowrasteh, "Alternatives to Detention Are Cheaper Than Universal Detention," Cato at Liberty, June 20, 20I8; Ingrid Eagly and Steven Shafer, "A National Study of Access to Counsel in Immigration Court," University of Pennsylvania Law Review I64, no. I (December 2015): I-91; Human Rights First, Immigration Court Appearances Rates, February 2018.

56. "The Latest: US Will Reassign 750 Border Inspectors," Associated Press, March 27, 2019.

57. Alan Gomez, "Wave of Cubans Finally Reach U.S. after Grueling Land Journey," USA Today, January 31, 2016.

58. Nomaan Merchant, "Autopsy: Migrant Child Who Died in US Custody Had Infection," Associated Press, March 29, 2019.

59. Amy Sherman and Miriam Valverde, "Fact-Checking Julián Castro's Claim That Asylum 'Metering' Caused Drowning of Father, Daughter," PolitiFact, June 27, 2019.

\section{CITATION}

Bier, David J. "Legal Immigration Will Resolve America's Real Border Problems.” Policy Analysis No. 879, Cato Institute, Washington, DC, August 20, 2019. https://doi.org/I0.36009/PA.879.

The views expressed in this paper are those of the author(s) and should not be attributed to the Cato Institute, its trustees, its Sponsors, or any other person or organization. Nothing in this paper should be construed as an attempt to aid or hinder the passage of any bill before Congress. Copyright (C 2019 Cato Institute. This work by Cato Institute is licensed under a Creative Commons Attribution-NonCommercial-ShareAlike 4.o International License. 